\title{
Notes on Books
}

the student, who will gain from the book a useful introduction to the study of medicine.

Surgical After-Treatment. By L. R. G. Crandon, A.M., M.D., and Albert Ehrenfried, A.B., M.D., Harvard Medical School. Second Edition. Pp. 831. With 265 Illustrations. Philadelphia : W. B. Saunders Co. 1912. Price 2气̄s. net.

$\mathrm{WE}_{\mathrm{E}}$ expressed a favourable opinion of this work when it appeared less than two years ago, and the second edition, which is now before us, in no way falls short of its predecessor. If we were to offer any criticism of the new issue it would be that, while the authors describe in sufficient detail the ordinary after-treatment of a plain-sailing case, they frequently fail us when we consult them regarding the steps to be taken when complications have arisen and things are not going smoothly.

\section{NOTES ON BOOKS.}

A Practical Medical Dictionary, by Thomas Lathrop Stedman, A.M., M.D. (Henry Frowde and Hodder \& Stoughton, 1911, price 21s.).It is impossible in the limited space at our disposal to give anything approaching a complete account of the comprehensiveness of this work. In the fifty thousand titles are included, in addition to medical words proper, dental, veterinary, chemical, botanical, electrical, and life insurance terms. The labour involved in the preparation of the Dictionary must necessarily have been stupendous and spread over a number of years, but neither time nor trouble has been spared in the effort to make it worthy of the name. The difficulties of synonyms, of alternative spellings, and of cross-references have been on the whole successfully overcome. In comprehensiveness and general handiness the volume constitutes the "last word" in medical dictionaries.

For the first time in its history The Extra Pharmacopceia of Martindale and Westcott (15th edition; London, H. K. Lewis) appears in two volumes, this change having become necessary on account of the growth of the subject-matter during the past two years. Volume I. deals, roughly, with therapeutic questions, Vol. II. with analytical and experimental work, both in reference to medicinal substances and clinical investigation. It is quite unnecessary for us to praise the way in which the Extra Pharmacopoia has been revised; its value as a mine of reference is too well attested to require further emphasis. The division into two volumes will, no doubt, be regretted by some, but we to the that it is a decided improvement. The subjects now relegated from second volume are daily bulking more largely in importance, and the more points of view it is well that they should be separated from and 7 re purely therapeutic part of the book. The volumes cost $14 \mathrm{~s}$. and 7 s. respectively, and may be purchased separately. 
In his preface to Children: Their Care and Management (Henry Frowde and Hodder. \& Stoughton, 1912, price 3s. 6d.), Dr. E. M. Brockbank says that "the object of his book is to offer to newlyqualified doctors and to mothers and nurses some practical advice on the everyday care of children at the nursery age." He need not in this book limit his remarks to newly-qualified doctors; some of the chapters, more especially the first one, on "natural or breast feeding," might be read with advantage by all general practitioners. In such a book as this, covering so much ground, and written also more or less in a popular manner, adverse criticism could no doubt be given; but we feel that the book is written on eminently safe and sound lines, and we can thus confidently recommend it, as giving much useful and practical advice on an all-important subject.

Modern Methods in Nursing, by Georgiana J. Sanders (W. B. Saunders Co, price 12s.), forms a complete guide for a nurse, from the time when she begins to select a training-school till she has charge of a ward. The perusal of Miss Sanders's manual gives a good idea of the fulness of the present-day curriculum. The book is not a mere compilation of facts from various text-books, but has obviously been written by one with a large experience in nursing. It gives us pleasure to recommend it.

Dr. Duckworth's Prehistoric Man (Cambridge University Press, 1912, 1s. net) provides a succinct account of the earliest phases of the history of mankind. No better introduction to this subject could be desired. The latest evidence on the subject is ably summarised, and the value of the book is enhanced by well-selected illustrations and a list of references. The high standard of the Cambridge manuals is worthily maintained in this volume.

Golden Rules of Skin Practice (4th edition), by David Walsh, M.D. (.John Wright \& Sons, Ltd., price 1s.), is a useful little book for car or carriage moments. The teaching is well in line with modern research. and as reliable as possible in this condensed form. The alphabetical arrangement is useful for ready reference.

Systematic Case-Taking, by Henry Lawrence M'Kisack, M.D., M.R.C.P.(Lond.) (Baillière, Tindall \& Cox, price $3 \mathrm{~s} .6 \mathrm{~d}$.), contains nine short chapters in which the examination of medical cases is briefly described. The book is an amplification of the ordinary case-taking form, and from this point of view is a good introduction to the ordinary text-books on clinical methods. Its chief value to the student, however, is the fact that the conclusions which may be drawn from clinical data are shortly stated. Some of the descriptions are too short to be easily understood by a junior student, and this is specially so in the chapter on the blood. In dealing with the nervous system the author states briefly the conclusions to be drawn from physical signs, and explains the meaning of many terms used in neurology. 
A handy text-book wherewith to refresh the memory as to the anatomy or physiology of the nervous system is as useful to the practitioner as to the student preparing for an examination. Dr. Lickley's The Nervous System (Longmans, Green \& Co., 6s. net) is an excellent manual of this type. It is copiously illustrated, and the only criticism we would pass on it is that Dr. Henry Head's researches on the sensory paths deserve fuller description than they receive.

The Enzyme T'reatment of Cancer and its Scientific Basis, by John Beard. D.Sc. (Chatto \& Windus), is a collection of papers previously published in such journals as the Lancet, Medical Record, etc. As such it suffers from the disabilities of similar collections, in that the chief contentions are repeated over and over again. At the same time it contains most interesting and in many ways most instructive reading.

The first edition of Dr. Sim Wallace's little book The Prevention of Dental Caries (Offices of the Dental Record, price 1s. 6d.) having been sold out within a few months, a second edition has been called for. The views of the author are becoming widely known, and we trust that this edition, which is apparently a reprint of the first but with a much handier size of page, will still further disseminate these views. We recommend the book as a short account of principles which if carried into practice will enormously lessen the amount of dental caries and the diseases that result from it.

The handbook of Ancesthetics in Dental Surgery, by Frank Coleman and Harvey Hilliard (H. K. Lewis, price 7s.), is a summary of their owin methods in practice and of the conclusions which they have drawn from their experience. Although the publishers have done their part well, the book has every appearance of having been hastily and carelessly written, for not only is there no attempt at literary style, but some of the sentences are ungrammatical and even unintelligible. There are a number of loose and inaccurate statements, and it would be interesting to know on what grounds the authors have come to some of their conclusions. Finally, we strongly dissent from the inclusion of chloroform as a dental anæsthetic, for whatever may have been the justification for its use in the past, there is absolutely none to-day.

Dr. Goepp in Dental State Baard Questions and Answers (W. B. Saunders Co., 1912, 12s. 6d. net) has collected the questions most commonly asked in the various States and has given answers to them, with the help of collaborators. It is a cram book of the usual type, and as such has no educational value, the information given being scrappy and disconnected.
Hygiene for Health Visitors, School Nurses, and Social Workers, by C. W. Hutt, M.A., B.C.(Cantab.), D.P.H.(Oxon.) (P. S. King \& Son, 1912, price 7s. 6d.). This is an excellent practical text-book for all interested in the social welfare and betterment of the poorer classes, and it summarises the required information in a way not hitherto done
in any single text-book. 
Leitfaden der Praktischen Kriegs-Chirurgie (Dresden, verlag von Theodor Steinkopf, 1912, price M.9.50).-Dr. Walter von Oettingen, who was in charge of a Red Cross field hospital in the Russo-Japanese War, states that he has endeavoured to write the kind of book which was required at that time by himself and his colleagues. His experience has obviously qualified him for the task, and he is to be heartily congratulated on the result.

Mr. C. F. Marshall's book on'Syphilis and Venereal Disease (Baillière, Tindall \& Cox, 1912, price 10s. 6d.) has been brought up to date by the addition to the first edition of chapters on the vaccine treatment of gonorrhea, the micro-biology of syphilis, the Wassermann reaction, and the arsenical treatment of syphilis. Mr. Marshall has presented a good account of recent work on these subjects, and his book may be commended to those in need of an up-to-date moderate-sized text-book treating venereal disease in a systematic manner.

\section{BOOKS RECEIVED.}

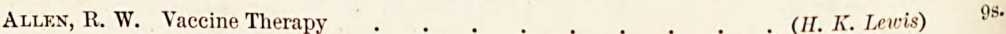

Armstrong, H. G., and J. M. Fortescue-Brickdale. A Manual of Infectious Diseases occurring in Schools . . . . . . . . . . (Wright \& Sons)

Borradaile, L. A. A Manual of Elementary Zoology . $\quad$ (Frowde, Hodder \& Stoughton) 10s. $6 \mathrm{~d}$. BovaIrd, D., JR. Internal Medicine . . . . . . • (J. B. Lippincott) $21 \mathrm{~s}$. Bury, J. S., and A. Ramsbottom. Clinical Medicine. Third Edition . $\quad$ (Griffin \& Co.) 17s. 6d. Canpbell, W. F., and Le Grand Kerr. The Surgical Diseases of Children

Chaplin, A. The Illness and Death of Napoleon Bonaparte . . _ (Appleton \& Co.) 25. Clayton-Greene, W. H. Pye's Surgical Handicraft. Sixth Edition . (Wright \& Sons) 12s.6d. Geiger, G. Précis Practique d'Électricité Médicale . • . • $\quad$ (Rousset, Puris) ${ }_{6} \mathrm{fr}$. Gibson, G. A. Life of Sir William Tennant Gairdner $\quad . \quad \cdot \quad \cdot \quad \cdot \quad$ (Maclehose \& Sons) 10s. 6d. Grasser, H. Générations Spontanées et l'Hétérogénie . $\quad . \quad$. $\quad . \quad$ (Rousset, Paris) $4 \mathrm{fr}$. Herschell, G. Elementary Clinical Pathology for Nurses . . . . (J. \& A. Churchill) 1 s. Jonks, E. Papers on Psycho-Analysis . • . . . . (Baillière, Tindall \& Cox) 10s. 6d. Kraepelin, E., and T. Johnstone. Lectures on Clinical Psychiatry. Third Edition

Lagleyze, P. Du Strabisme (Baillière, Tindall \& Cox) $10 \mathrm{~s} .6 \mathrm{~d}$. (Rousset, Paris) $15 \mathrm{fr}$.

Lemingham, J. C. G., and J. A. Arkwright. The Carrier Problem in Infectious Diseases (Edward Arnold) 12s. 6d.

M'CAy, D. The Protein Element in Nutrition.

Marchildon, J. W. The Wassermann Reaction (Edward Arnold) $10 \mathrm{~s} .6 \mathrm{~d}$. . . . $\quad$ (Henry Kimpton) 6s. $6 \mathrm{~d}$ Marshall, C. D. Diseases of the Eyes . . . . . . (Frowde, Hodder \& Stoughton) $10 \mathrm{~s} .6 \mathrm{~d}$. Pfrcival, A. S. Geometrical Opties . . . . . . . (Longmans, Green \& Co.) 4s. 6d. Price, J. A. P. Hoblyn's Dictionary of Medical Terms. Fifteenth Edition (Bell \& Sons) $10 \mathrm{~s} .6 \mathrm{~d}$. RACHFord, B. K. Diseases of Children . . . . . . . (Appleton \& Co.) $3 \mathrm{fr}$. Schwaeble, R. La Vie du Règne Minéral . $\quad . \quad+\quad . \quad$. $\quad$ (Rousset, Paris) 3 fo

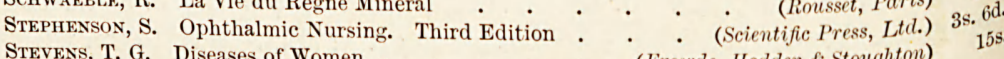
Stevens, T. G. Diseases of Women - • • • · $\quad$ (Frowde, Hodder \& Stoughton) The Surgical Clinies of John B. Murphy. Vol. I., No. 5, October 1912 (W. B. Saunders Co.) THE "Wellcome" Photographic Exposure Record and Diary, 1913

Turner, W., and E. R. Carling. Treatment after Operation (Burroughs Wellcome d Co.) $10 \mathrm{~s} .6 \mathrm{~d}$. Villiger, E. Brain and Spinal Cord $16 \mathrm{~s}$.

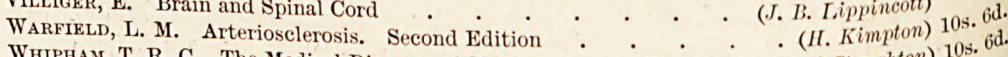
Whipham, T. R. C. The Medical Diseases of Children . $\quad$ (Frowde, Hodder \& Stoughton) $10 \mathrm{~s}^{6 \mathrm{~d} .}$ 